\title{
Managing the academic talent void: Investigating factors in academic turnover and retention in South Africa
}

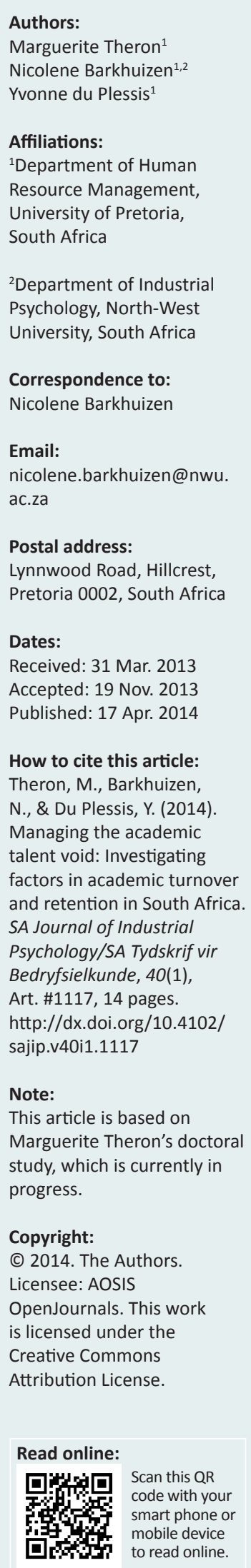

Orientation: Globally, the demand for academic staff in higher education is expected to continue to increase. The South African situation is exacerbated by the so-called 'retirement swell' and turnover and retention problems; measurements to diagnose these factors remain limited.

Research purpose: This study aimed to investigate the factors that influence turnover and retention of academic and to validate the developed talent retention diagnostic tool for use in South African higher education institutions.

Motivation for the study: Limited research currently exists on the retention factors of academic staff in the South African context.

Research approach, design and method: Using an investigative quantitative research approach, the tool was administered to a convenience sample of academics $(n=153)$ in 13 higher education institutions.

Main findings: The results showed an array of distinguishing turnover and retention factors and proved the tool to be a valid and reliable measure. Over half the respondents indicated slight to strong dissatisfaction with compensation and performance management practices. Significantly, 34\% indicated that they considered exiting their academic institution, citing unhappiness about compensation, as the most likely reason, whilst $74.5 \%$ have previously looked for another job.

Practical/managerial implications: The research highlights key areas (i.e. compensation, emotional recognition, a bonus structure that reflects employee contribution, performance management systems, mentorship and career development opportunities) that higher education should attend to if they want to retain their key and talented academic staff.

Contribution/value-add: The results contribute to new knowledge on the factors that contribute to turnover and retention of academic staff and present a valid and reliable measure to assess these retention factors.

\section{Introduction}

Globally, the demand for academic staff in higher education institutions (HEIs) is increasing, and is expected to continue to increase. Concurrently, retention problems and intention to leave are exacerbating the problem, and a so-called academic 'retirement swell' is also evident, leaving HEIs with no option but to seriously investigate retention of academic staff (HESA, 2011; Pienaar \& Bester, 2008). According to Higher Education South Africa (HESA), and from the literature, it is evident that HEIs are currently facing significant challenges in retaining key and talented academic staff (HESA, 2011; Mokoditoa, 2011; Robyn, 2012). Several explanations have been offered to elucidate the reasons for these high turnover rates, which include, amongst others, uncompetitive remuneration packages and incentives, unfair promotion policies, a lack of adequate state and research funding, institutional cultural issues and expanding student numbers resulting in heavier workloads (Bitzer, 2008; De Villiers \& Steyn, 2009; HESA, 2011; Netswera, Rankhumise \& Mavundla, 2005; Ntshoe, Higgs, Higgs \& Wolhuter, 2008; Pienaar \& Bester, 2008).

Retaining academic staff is, of course, vital, as they ensure that universities accomplish their visions and missions, and become centres of excellence ( $\mathrm{Ng}^{\prime}$ ethe, Iravo \& Namusonge, 2012). Indeed, the government expects HEIs to play a fundamentally greater role in the development of the country through a range of initiatives to accelerate economic growth, reduce poverty and supply scarce skills (CHE, 2008; HESA, 2011). The importance of these initiatives is evidenced by the fact that the World Economic Forum (2011) in its Global Competitiveness Report rated South Africa 88th out of 134 countries for labour market efficiency and 93rd out of 134 countries for innovative potential, due to low enrolment in higher education and training. 
It therefore stands to reason that South African HEIs cannot afford to lose valued and talented academic employees if they are to contribute to the sustained development of the country and its people over the long term (Netswera et al., 2005; Pienaar \& Bester, 2008). When top-performing employees exit, they leave a void that is often costly to fill and challenging to manage (Robison, 2008). Studies estimate replacement costs at $100 \%$ to $150 \%$ of the annual salary of such an employee (Somaya \& Williamson, 2008). The impact of voluntary resignations of individuals on the workgroup and the organisation includes psychological and intangible consequences, such as loss of the knowledge, skills and experience of departing employees, disruption of service delivery, declining morale, disruptions of the productivity of the work group and stress caused by vacancies (Pienaar \& Bester, 2008; Pinkowitz, Moskal \& Green, 2009; Smither, 2003; Whitt, 2006).

Despite the acknowledgement of these talent management challenges, there still remains limited empirical research in developing countries to explain this phenomenon, let alone measurements that can be used to diagnose and prevent the turnover of academic staff ( $\mathrm{Ng}^{\prime}$ ethe et al., 2012) leaving an academic void. According to Harman, Lee, Mitchell, Felps and Owens (2007), theory and research studies on turnover have attempted to answer the following questions:

- Why do people voluntarily leave a position and an organisation?

- Why do people stay with an organisation?

The fact that there seems to be no definitive answers available academically implies that turnover and retention research continues to be an important research topic to pursue, as the retention of key, top-performing employees remains essential for effective organisations ( $\mathrm{Ng}^{\prime}$ ethe et al., 2012; Pienaar \& Bester, 2008). Turnover, in essence, is a measure of organisational effectiveness (Boshoff \& Mels, 2000), with the implicit assumption being that a stable workforce is required to meet organisational objectives (Kontoghiorghes \& Frangou, 2009).

Lee, Gerhart, Weller \& Trevor (2008, p. 651) call for researchers in the field of employee turnover and retention to obtain data on both 'leavers' and 'stayers', in order to prevent an incomplete, one-sided view of the phenomenon. Organisational-level data can provide knowledge about the 'leavers' by determining the specific context of who is leaving, where they are going, what knowledge and skills they are taking with them and what this costs the organisation (Allen \& Griffeth, 1999; Whitt, 2006). In contrast, there is limited organisational data available on the reasons why employees choose to stay (Kontoghiorges \& Frangou, 2009). Smither (2003, p. 20) recommends 'routine diagnostic checks' on top-performing employees to ensure that they are productive and content. This would imply obtaining data on those employees who have chosen to stay and have an understanding of various factors that they are satisfied or dissatisfied with in the institution. Against this background, the main objective of this research study was to investigate and validate the factors relating to the turnover and retention of academic staff in South African public HEIs.

This article is structured as follows. Firstly a literature review is provided with the possible factors that should be considered in constructing a measurement scale for academic turnover and retention in South African HEIs. This is followed by a discussion of the research method employed for this study. Flowing from the method, the empirical results of the research are reported. The research concludes with a discussion of the key results and recommendations for both practice and future research.

\section{Literature review}

The retention of existing employees and the ability to entice a stream of new employees is a necessity for the success and advancement of organisations (Cascio, 2006). Retaining skilled workers is regarded as a critical strategic human resources issue (Tanova \& Holtom, 2008). The majority of the research and theoretical work in the field of turnover and retention has focused on employee turnover, with the original assumption being that if researchers can identify why employees leave, they will be able to identify why employees stay (Harman et al., 2007). The prevailing research holds that if a variable is negatively related to turnover through empirical research, then a positive impact on retention may be assumed (Steel, 2002).

Retention research often uses measurements of intention to quit, or actual voluntary turnover, and then reports associations with constructs that are theoretically linked to retention. Due to the scarcity of actual employee retention research where cohorts of individuals have been monitored over time (Steel, 2002; Waldman \& Arora, 2004), turnover research continues to inform our current understanding of employee retention.

\section{Distinguishing voluntary and involuntary turnover}

When conducting research into voluntary turnover, the aims are to understand, predict, prevent and effectively manage turnover (Harman et al., 2007). Turnover has traditionally been viewed as a negative phenomenon that needs to be managed in order for the organisation to remain effective (Shaw \& Gupta, 2007). Involuntary turnover is controlled by the organisation, whereas voluntary turnover is within the control and free will of the employee. Thus, the causes and consequences of involuntary turnover are quite different to the causes and consequences of voluntary resignations (Shaw, Delery, Jenkins \& Gupta, 1998). Hay (2002) raises the concern that failure to manage poorly performing employees through dismissals may actually lead to voluntary resignation of top-performing employees. Poorly performing employees who shirk their work responsibilities place an unfair burden on top-performing employees, which, in turn, may lead to resentment, accumulated dissatisfaction and eventual resignation by top-performing employees (Hay, 2002). 
When considering research findings, it is important to establish whether aggregate measures of turnover were used without distinguishing between voluntary or involuntary turnover. For example, Huselid (1995) used an aggregate measure of turnover to determine the interaction between employment practices and organisational productivity. In contrast, Shaw et al. (1998) utilised the distinction between voluntary and involuntary turnover in their study of the effect of human resources (HR) practices on turnover, and the authors confirm that the findings differ for resignations and involuntary terminations. The focus of the present study was on voluntary turnover, with the understanding that the total separation rate or total turnover rate comprises both voluntary and involuntary turnover (Bontis \& Fitz-enz, 2002).

\section{Distinguishing avoidable and unavoidable turnover}

Turnover can be regarded as avoidable if the organisation could have done something to prevent the employee from leaving (Morrell \& Arnold, 2007). At times, there may be nothing that can be done to prevent a specific employee from leaving, but information gathered about the reasons for resignations may assist in identifying avoidable turnover and implementing interventions that could prevent future voluntary turnover (Morrell, Loan-Clarke \& Wilkinson, 2001). Avoidable turnover can be identified retrospectively in one sample of employees who have already resigned, after which interventions can be developed for employees still employed with the organisation (Morrell \& Arnold, 2007). Avoidable turnover can also be identified where employees have expressed turnover intentions, but have not yet resigned.

Unavoidable turnover is described as voluntary resignations due to reasons over which the organisation has no control, which are usually not work-related. Regarding turnover that is unavoidable, the organisation should focus on identifying strategies that will minimise the disruption and inconvenience of the departure (Morrell et al., 2001). At times, the best course of action may be to manage the event after the fact (Lee, Mitchell, Wise \& Fireman, 1996). Lee et al. (2008) propose that different types of turnover require different strategies; retention strategies are applicable to avoidable, voluntary turnover. Well-timed interventions could encourage the employee to stay and avoidable turnover can be managed through prevention models. Where turnover is not avoidable, a manager needs to minimise the disruption caused by the resignation, instead of trying to prevent it (Morrell et al., 2001). Where turnover cannot be prevented, the costs and consequences of voluntary turnover need to be considered (Pinkowitz et al., 2009).

\section{Measurement of employee turnover and retention}

Research studies on turnover use either actual turnover (employees who have already left the organisation) or intention to quit (employees who state that they intend to leave) as measurement indicators (Morrell et al., 2001). Researchers have found that turnover intentions are positively related to actual turnover behaviour (Allen, Shore \& Griffeth, 2003), but the two variables cannot be assumed to measure turnover in the same way. There are contradictory findings when considering an independent variable such as perception of organisational support (POS) that indicate significant differences when the outcome variable is actual turnover as opposed to intention to quit: Zhao, Wayne, Glibkowski and Bravo (2007) found that POS is significantly related to intention to quit, but not related to actual turnover.

Actual turnover figures are preferred to intention-to-quit figures, as the latter represent the 'subjective probability' that an employee will leave (Zhao et al., 2007, p. 647), whilst actual turnover figures provide a more accurate representation of employee outcomes (Tanova \& Holtom, 2008). Intention to quit has been studied in cross-sectional studies to investigate a potential relationship between an independent variable, such as satisfaction with performance appraisals, and intention to quit as the dependent variable (Du Plessis, Stanz \& Barkhuizen, 2010; Veldtman, 2011). Employees who intend to quit may still resign at some point in the future, or they may choose to stay; therefore, longitudinal studies or repeat episodic measurements of the variables being examined should ideally use actual turnover figures at a later stage (Morrell \& Arnold, 2007). When considering turnover intentions and actual turnover in the same study, Vandenberghe and Bentein (2009) found a link between affective commitment to supervisors and turnover intentions in two samples, whilst in the third sample affective commitment to supervisors was the only significant predictor of actual turnover. Due to anonymity constraints the present study only considered turnover intentions.

Performance measures can also be used as a retention measure. Performance measures are indicators of the extent to which employees are helping the organisation meet its business objectives (Malik \& Ghafoor, 2011). Performance measures can be linked to in-role behaviours that are recognised by the organisation's formal reward system, or extra-role behaviours such as organisational citizenship behaviour (Zhao et al., 2007). For the purposes of this study, it was important to determine whether or not the performance appraisal system was regarded as fair by employees, as this may affect employee retention and turnover (Pienaar \& Bester, 2008). Pienaar and Bester (2008), for example, found that early career academics are likely to leave their institutions when performance appraisals are unfair, discriminative and not applied consistently. Whitford and Coetsee (2006) propose that the underlying performance management philosophy of the organisation towards talented individuals needs to be specified before effective performance management criteria can be applied.

\section{Turnover and retention of academics in the South African context}

Attempts to explain voluntary turnover by examining external issues such as labour market factors have been a longstanding 
tradition in turnover research (Morrell et al., 2001). Labour market and external factors have been described as 'pull factors', and include the availability of alternative jobs (Lee \& Mitchell, 1994, p. 51). The availability of alternative jobs can represent 'ease of movement', which can be defined as employees' perceptions of whether or not it is easy to move to another job (Lee et al., 2008, p. 651).

Demand in the labour market is considered an antecedent to turnover (Lee \& Mitchell, 1994). In the South African HE context, about half of the academic professoriate will be retiring in less than a decade from now and there is a concern that the academic pipeline is insufficient to fill the retirement gap (HESA, 2011). As a result, there will be a critical shortage in the academic supply, and the growing demand will not be met. Labour market factors are viewed as moderating employee turnover, as high unemployment rates would imply that fewer job alternatives are available, and leaving a job is perceived as costly (O'Reilly, 1991).

Due to the scarcity of local South African benchmarking information, local studies often need to rely on international benchmarking studies in academia from the United Kingdom or Europe (Jongbloed, 2012; Metcalf, Rolfe, Stevens \& Weale, 2005). In the absence of local benchmarking information, South African studies to determine turnover or retention of scarce skills are guided by information from the Department of Labour on which sectors of the market have the highest proportion of vacancies (Netswera et al., 2005).

Current socio-economic realities will need to be incorporated into effective contextual management of turnover, as return on investment and cost of retention strategies become increasingly relevant during times of economic recessions (Hinkin \& Schriesheim, 2009; Williamson \& Zeng, 2009). There are also indications that, when a depressed economy leads to a lack of salary increases, employee attitudes, such as satisfaction and commitment, in addition to intention to leave, are also affected (Taylor, Murphy \& Price, 2006). Both CHE (2008) and HESA (2011) acknowledge that compensation is a key reason why academics are leaving HEIs, and that compensation structures should be customised to retain academics. According to HESA, the salary differentials between the private sector and HEIs are sizable and growing. Uncompetitive remuneration packages result in academics being poached by the private sector.

Another significant problem is the fact that universities in sub-Saharan Africa continue to operate under conditions that are under-resourced, which poses significant challenges for the scholars concerned (HESA, 2011; Mouton, 2010). Over the past two decades, state and research funding of public universities have significantly deteriorated (De Villiers \& Steyn, 2009; Mouton, 2010). As a result, public university academics have transformed into 'academic capitalists' in order to generate a third stream of income that will benefit the individual, the institution and the country (Ntshoe et. al., 2008). The work of academics has thus become more emotionally demanding and fragmented, which implies a loss of professional autonomy, scholar identity and psychological ownership (Bitzer, 2008).

However, most HEIs battle with reforming and transforming staff development towards national imperatives. Conflicts of interest are evident in the focus on staff development in HEIs' national imperatives (Botha \& Potgieter, 2009). A report by HESA (2011) indicates that the budget allocation and funding by the government are not sufficient to cater for staff and student development. Insufficient career opportunities and inadequate academic staff development have implications for the career motivation, career success and employability of academics, which can ultimately lead to the devaluation of the professoriate (Bitzer, 2008; Buddeberg-Fischer, Stamm \& Buddeberg, 2009).

All higher education leaders should therefore address the core competencies and human characteristics that are required for successful academic careers, responsible citizenship and a good quality life (Chickering \& Stewart, in Netswera et al., 2005). This means that the 'talent mindset' of higher education leadership should focus on acquiring a holistic understanding of attracting, developing and sustaining academic talent (Salopek, in Netswera et al., 2005). According to Phillips and Connell (in Pienaar \& Bester, 2008), top management underestimates the value and gravity of talent retention and, consequently, the reasons for and solutions to labour turnover are not correctly identified. Netswera et al. (2005), for example, found that HEI managers focus on profits, business sustenance and justification of spending, whereas employees are driven by introverted interests such as development, monetary rewards and personal fulfilment.

In the light of the above discussion, this research aims to answer the following research questions:

- Which factors encourage academic employees to stay in HEIs?

- Which factors encourage academic employees to leave HEIs?

- To what extent are academics satisfied with current institutional retention practices?

- To what extent are academics considering exiting their HEIs?

\section{Research design Research approach}

An investigative quantitative research approach was followed by administering a talent retention diagnostic tool, developed based on the literature review and interviews with HR practitioners and employees to substantiate factors for inclusion in the measurement scale. The scale development processes of DeVellis (1991) and Hinkin (1995) have been recommended as a standard for the development of new multiitem measures (Tharenou, Donohue \& Cooper, 2007, p. 164). The steps in the scale development process as applied to the present research are described in Table 1. 
TABLE 1: Scale development process.

\section{Scale development step}

Step 1: Application of a theoretical basis to develop the items: Establish the parameters of the construct of interest or latent variable. Construct needs to be defined and relationships with other variables needs to be established (Tharenou et al., 2007, p. 165)

Step 2: Item generation: Design individual items which are questions or statement to measure the constructs. Items should reflect the scale's purpose (DeVellis, 1991, p. 54). The number of items in the initial 'item pool' can be three to four times as many as intended for the final scale (DeVellis, 1991, p. 57).

Step 3: Determine the scale and measurement format: Include type of scale, format of items, number of response categories, odd or even numbers of responses and response format (DeVellis, 1991, pp. 61-74).

Step 4: Conduct an item analysis to eliminate inadequate items: Include use of an expert panel. Evaluation by an expert sample can help determine content validity (DeVellis, 1991, p. 43).

Step 5: Select validation items that can be administered to developmental sample: May include measures that can provide clarity on extent of convergent validity or divergent validity (Tharenou et al., 2007, p. 165). May include social desirability scales or other response tendencies. May also need to include additional measures of the constructs to determine convergent validity or construct validity (DeVellis, 1991, p. 77).

Step 6: Design and conduct developmental study: Administer scale items and validation to a sample of respondents. Number of persons in sample is recommended as a minimum of 150 (Hinkin, 1995) to 300 or more (Nunnally, in DeVellis, 1991).

Step 7: Evaluate the items: A basic items analysis will help to identify and remove ambiguous items, and items that do not discriminate between the respondents
(Tharenou et al., 2007, p. 167). At this stage basic statistics such as means, standard (Tharenou et al., 2007, p. 167). At this stage basic statistics such
deviation and frequencies can help to identify inadequate items.

Step 7a: Determine construct validity of the measure: Can use exploratory factor analysis (Tharenou et al., 2007, p. 168), principle components analysis or confirmatory factor analysis (Hinkin, 1995).

Step 7b: Determine the convergent validity of the measure: Determine whether there are alternative explanations for what the scale measures (Tharenou et al., 2007 , p. 165). Obtain alternative measures of the construct of interest and compare to the measures from the scale. May require administering existing measures to the developmental sample. Statistical analysis includes correlation coefficients.

Step 7c: Determine the divergent validity of the measure: Determining whether the scale is related to measures it should not be related to (Tharenou et al., 2007, p. 165).

Step 7d: Assess the reliability of the scale: Possible to use internal consistency reliabilities, test-retest reliabilities and multiple measures of reliability (Tharenou et al. 2007, p. 168)

Step 8: Optimise scale length: Consider effect of length of scale on reliability and also factors such as respondent fatigue.
Application in present study

Step 1a: Identify the parameters of the turnover and retention theory to be included in the measurement scale. These informed the conceptual framework for the study. Step 1b: Conduct semi-structured interviews with key respondents to help determine the parameters of turnover and retention data required to be included in the the parameters of turnover and retention data required to be included in the
measurement scale. Data was collected and analysed qualitatively. This step was measurement scale. Data was collected and analysed qualitatively. This step was African situation which may not be adequately dealt with if only theoretical analysis is African situation which may not be adequ
used to establish the content domain.

Step 2: Item generation based on theoretical relationships between constructs and the qualitative analysis of the interviews. Statements were generated rather than questions.

Step 3: Format of items using statements in a Likert response format (DeVellis, 1991, p. 68) was developed. Additionally, checklist-style questions and open-ended questions were included.

Step 4: Expert panel of seven academics reviewed scale and were provided with construct definitions and asked to rate items in terms of adequacy, relevance, conciseness and potential confusing wording. Revised scale was pretested on 18 respondents.

Step 5: This research did not include social desirability scales. The scale does use repetition of items that measure the same construct in different sub-scales to determine if similar or different responses were provided.

Step 6: Design and conduct developmental study by administering employee retention diagnostic items and validation items to sample of 150-300 employees within tertiary academic institutions in South Africa.

Step 7: Evaluate the items. Followed advice of (DeVellis, 1991, pp. 82-85) to include item-scale correlations, item variance, item means and coefficient alpha when appropriate.

Step 7a: Determine construct validity of the measure by conducting exploratory factor analysis in present study and, at a later stage, confirmatory factor analysis. For confirmatory analysis a larger sample will be required.

Step 7b: Convergent validity cannot be determined in the current study.

Step 7c: Determine the divergent validity of the measure. Determine whether method effects are influencing the scale findings. May also require a criterion-related study and a larger sample than the present sample.

Step 7d: Assess the reliability of the scale. Determine internal consistency reliabilities. Test-retest reliabilities cannot be considered as the respondents are anonymous. Some items will be expected to change over time, such as intention to quit or satisfaction. The planned alternative is to administer the scale to another sample which would enable multiple measures of reliability to be compared.

Step 8: Optimise scale length. Due to the nature of the scale (a diagnostic tool that can be used regularly) the scale needs to be short enough to avoid respondent fatigue so considerable attention will be given to optimising scale length.

\section{Research method}

This article reports the results relating to step 6 of the DeVellis (1991) scale development process.

\section{Research participants}

The respondents were academic staff from 13 public HEIs in South Africa. A total of 330 surveys were distributed to a purposive convenience sample of academics. A response rate of $46 \%$ ( $n=153)$ was achieved. According to Hinkin (1995), a minimum of 150 respondents is needed for a developmental study administering employee retention diagnostic items and validating the items. Another key consideration is the number of subject-to-variable (STV) ratio for factor analysis. A number of researchers maintain that the STV ratio should not be less than five for factor analysis (Field, 2009). The longest section in the pilot questionnaire administered in the present study contained 17 items, which meant that the STV ratio was nine. This was close to the minimum STV of 10 respondents per item recommended by Garson (2011). Based on the above, the sample size was adequate to achieve the main objective of this study: to investigate and validate the factors relating to the retention of academic staff in South African public HEIs.

There were slightly more male respondents in this research, comprising $53.6 \%$ of the sample whilst female respondents made up $46.4 \%$ of the sample. The ethnicity of the sample emerged as black South Africans at $54.2 \%$ followed by white South Africans (41.8\%), whilst the remaining 4\% were foreigners (non-South Africans). The age group with the most number of respondents was between $40-49$ years (34\%); on an accumulative basis $63 \%$ of respondents were older than 40 years of age. The largest single group of respondents is in possession of a master's degree $(40.5 \%)$, and a combined $79.7 \%$ of respondents have either a master's degree or doctoral degree. The largest grouping of respondents are employed at lecturer level $(37.9 \%)$, followed by senior lecturer level $(24.8 \%)$. The majority of respondents had up to 10 years' work experience in academia $(66.7 \%)$, and had been employed for up to five years in their current job (68\%). The majority of employees report working in excess of 40 hours a week $(62.7 \%$ of sample). 


\section{Measuring instrument}

As mentioned previously, a talent retention diagnostic tool was developed by Theron (2012) to determine the turnover and retention factors for academic staff. Item generation was based on the theoretical relationships between constructs and the qualitative analysis of semi-structured interviews with 11 key respondents from six distinct South African organisations. These interviews were conducted to help determine the parameters of turnover and retention data required to be included in the measurement scale. These key respondents were designated experts with specialised knowledge, experience and skills in talent retention or voluntary turnover and exit management research in their respective organisations. The findings from the interviews were used to generate the item pool for the proposed employee retention measurement scale using the methodology recommend by Hinkin (1995) and DeVellis (1991). Statements were generated rather than questions. A total of 18 surveys were pretested with revisions made based on the recommendations of the participants. The participants in the pretest process included the 11 key respondents mentioned above and an additional seven academic reviewers. Ethical clearance was obtained from the relevant authorities for the research method and the questionnaire itself.

This tool assumed the format of a survey questionnaire consisting of the following five sections:

- Section A (biographical information): Biographical information obtained included university, gender, age, home language, ethnicity, education, years of service and number of years in current job.

- Section B: This section focused on the factors that would encourage employees to stay in the organisation. The two most dominant retention factors identified in the key respondent interviews, namely compensation and recognition and management support, were included in this section. Firstly, the respondents were requested to indicate how they feel about compensation and recognition for the work that they do. This part of the questionnaire measures nine compensation and recognition-related items on a six-point Likert type scale ranging from 1 (strongly disagree) to 6 (strongly agree). Secondly, the respondents were requested to indicate how they rated their relationship with their immediate supervisor, manager or direct line manager. Nine items referring to trust, communication, feedback, career development, communication and performance appraisals were presented using the six-point Likert scale ranging from 1 (strongly disagree) to 6 (strongly agree).

- Section C: This section focused on the factors that might influence respondents to leave the organisation. Firstly, the respondents were required to indicate whether they had been searching for alternative employment. Respondents were required to respond to eight job search-related questions including whether or not they had applied for jobs inside or outside of academia. They could select one or more responses that clarified the nature of their job search. Secondly, the respondents were requested to indicate the five most likely reasons, out of 18 options provided, regarding why they would leave their institutions. The 18 options were identified from the literature and the qualitative analysis of the key respondent interviews and included 'push factors', 'pull factors', avoidable and unavoidable turnover options (Lee \& Mitchell, 1994, p. 51; Morrell \& Arnold, 2007). Examples of these 18 options include 'unhappy about career development opportunities', 'would leave for a promotion', 'would leave to study further', 'would leave if my spouse was transferred' and 'would leave for family responsibilities'.

- Section D: This section focused on the respondents' satisfaction with 17 items related to HR and HEI practices. Responses were measured on a four-point Likert scale ranging from 1 (extremely dissatisfied) to 4 (extremely satisfied). An open-ended question was included to allow respondents to elaborate on the practices with which they were dissatisfied. The content of the items was generated from the results of the interviews and academic reviewers. The reason for including satisfaction items was based on the literature review including the recommendation by Smither (2003, p. 20) to include 'routine diagnostic checks' on the level of employee satisfaction. Examples of these items include satisfaction with 'sufficient access to information in order to do my job', 'institutional leadership' and 'talent management policies in the institution'.

- Section E: The final section focused on the respondents' intention to leave the organisation and consisted of three items, with responses measured on a six-point Likert scale ranging from 1 (strongly disagree) to 6 (strongly agree). In a previous study in South Africa, Du Plessis et al. (2010) obtained acceptable Cronbach's alpha internal consistencies of 0.883 when applying Cohen's (1993) intention to quit scale. The intention to leave measure in the present study was similar to the three-item intention to quit scale developed by Cohen, with slight variations.

The validities and reliabilities of the measurements contained in Sections B, D and E were determined, and are reported in this research study. Section $C$ contained ranking items and single job search item selections, which are described using frequencies and percentages.

\section{Data analysis}

Data analysis was carried out with the aid of SPSS software. Scale measures do not necessarily align with the five sections of the measurement instrument. The five sections of the measurement instrument did not all use Likert-type scales. Section C contained ranking-type questions and selection of one or more job search-related statements. The appropriateness of the data for factor analysis of the different scale measures (i.e. compensation and recognition scale, management support scale, satisfaction with institutional practices scale and intention to quit scale) was determined by applying the Kaiser-Meyer-Olkin (KMO) measure of sampling adequacy (MSA) and Bartlett's test of sphericity to the inter- 
item correlation matrix of the measurement instruments. The KMO measure determines the degree of inter-correlations between the variables (Field, 2009; Hair, Black, Babin \& Anderson, 2010). According to Hair et al. (2010), a KMO measure of 0.6 or above is considered acceptable for factor analysis. Exploratory factor analysis was used to determine the factor structure for the scales in this sample. A cut-off point of 0.32 was used for variables, to allow for interpretation (Tabachnick \& Fidell, 2001). Cronbach's alphas were used to determine the reliability of the scale and its items. A cut-off point of 0.7 was used as a guideline for acceptable reliabilities (Field, 2009). Descriptive statistics such as means, standard deviations, skewness, kurtosis and cross-tabulations were used, due to the descriptive nature of this study.

\section{Results}

The results are reported according to the stated research questions.

\section{Factors that would encourage academics to stay in the HEls}

Compensation and recognition, and management support were identified as possible factors that could encourage respondents to stay in their institution. Firstly, the respondents' perceptions of their compensation and recognition are reported.

\section{Compensation and recognition}

The nine-item compensation and recognition scale obtained an acceptable KMO measure of 0.801 for factor analysis. An exploratory factor analysis using the principal component method was conducted on the nine items of the compensation and recognition scale. The results showed one underlying factor for the scale that explained $51.887 \%$ of the variance. The item loadings were acceptable, ranging from 0.629 to 0.782. The factor was labelled compensation and recognition. The descriptive statistics and reliabilities of the compensation and recognition scale and its items are reported in Table 2.

The results in Table 2 show Cronbach's alpha reliabilities for the compensation and recognition scale at 0.881 , which is above the value of 0.7 frequently regarded as acceptable (Hair et al. 2010; Hinkin, 1995). The sample is negatively skewly distributed. The overall mean score and frequency distribution of the compensation and recognition scale (3.35) shows that $52.7 \%$ of respondents express slight to strong disagreement about the adequacy of the compensation practices in their respective HEIs, whilst an additional 32.8\% only slightly agree that these practices are adequate. Looking at the frequency distribution of the different compensation items, it is evident that $56.2 \%$ of the respondents express slight to strong disagreement that their basic salary is adequate and $53 \%$ express slight to strong disagreement that the bonus structure is fair. The statement that emerges as having the lowest mean (2.85) is: 'My bonus structure reflects my contribution to the institution'; frequency analysis of responses shows that $61 \%$ of respondents are in slight to strong disagreement with this statement. The bonus structure thus presents itself to be the most problematic compensation practice for the current sample.

Recognition items in the scale include adequate emotional recognition and agreement that the employee is praised and thanked for the work that they do. Although the majority of employees in the present study perceived adequate emotional recognition ( $57 \%$ of sample), this still implies that $43 \%$ of the employees do not perceive the emotional recognition they receive to be adequate. In contrast, there is a $67 \%$ agreement amongst respondents that they are being praised and thanked for the work that they do.

\section{Support from manager, supervisor or direct line manager}

The nine-item management support scale obtained an acceptable KMO measure of 0.891 for factor analysis. An exploratory factor analysis using the principal component method was conducted on the nine items of the management support scale. The results showed one underlying factor for the scale that explained $66.566 \%$ of the variance. The item loadings were acceptable, ranging from 0.727 to 0.884 . The factor was labelled management support. The descriptive statistics and reliabilities of the management support scale and its items are reported in Table 3.

TABLE 2: Descriptive statistics and reliabilities of the compensation and recognition scale and its items.

\begin{tabular}{|c|c|c|c|c|c|c|c|c|c|c|c|}
\hline Factor and items & $\begin{array}{l}\text { Strongly } \\
\text { disagree }\end{array}$ & Disagree & $\begin{array}{c}\text { Slightly } \\
\text { disagree }\end{array}$ & $\begin{array}{l}\text { Slightly } \\
\text { agree }\end{array}$ & Agree & $\begin{array}{l}\text { Strongly } \\
\text { agree }\end{array}$ & M & SD & Skew. & Kurt. & $\alpha$ \\
\hline \multicolumn{12}{|l|}{ Factor } \\
\hline Compensation and recognition scale & 7 & 30 & 40 & 48 & 18 & 3 & 3.35 & 1.083 & -0.045 & -0.69 & 0.882 \\
\hline \multicolumn{12}{|l|}{ Items } \\
\hline Basic salary is adequate & 28 & 38 & 20 & 35 & 26 & 6 & 3.07 & 1.5 & 0.136 & -1.18 & 0.864 \\
\hline Medical aid benefits are adequate & 14 & 22 & 16 & 36 & 53 & 12 & 3.84 & 1.467 & -0.55 & -0.805 & 0.877 \\
\hline Pension benefits are adequate & 17 & 20 & 27 & 35 & 40 & 13 & 3.66 & 1.488 & -0.312 & -0.914 & 0.868 \\
\hline Praised and thanked & 20 & 16 & 13 & 48 & 43 & 12 & 3.75 & 1.497 & -0.571 & -0.715 & 0.875 \\
\hline Fairly compensated & 21 & 32 & 20 & 44 & 29 & 5 & 3.28 & 1.435 & -0.129 & -1.106 & 0.863 \\
\hline Bonus structure is fair & 31 & 25 & 23 & 29 & 32 & 10 & 3.24 & 1.612 & 0.002 & -1.266 & 0.878 \\
\hline Incentives and perks & 29 & 29 & 22 & 41 & 24 & 8 & 3.17 & 1.517 & 0.017 & -1.12 & 0.864 \\
\hline Bonus structure reflects contribution to the institution & 39 & 34 & 19 & 36 & 19 & 5 & 2.85 & 1.508 & 0.261 & -1.148 & 0.862 \\
\hline Adequate emotional recognition & 18 & 27 & 21 & 46 & 29 & 12 & 3.5 & 1.474 & -0.181 & -0.942 & 0.872 \\
\hline
\end{tabular}

M, mean; SD, standard deviation; Skew, skewness; Kurt, kurtosis; $\alpha$, alpha. 
TABLE 3: Descriptive statistics and reliabilities of the management support scale and its items.

\begin{tabular}{|c|c|c|c|c|c|c|c|c|c|c|c|}
\hline Factor and items & $\begin{array}{l}\text { Strongly } \\
\text { disagree }\end{array}$ & Disagree & $\begin{array}{c}\text { Slightly } \\
\text { disagree }\end{array}$ & $\begin{array}{c}\text { Slightly } \\
\text { agree }\end{array}$ & Agree & $\begin{array}{l}\text { Strongly } \\
\text { agree }\end{array}$ & M & SD & Skew. & Kurt. & $\alpha$ \\
\hline \multicolumn{12}{|l|}{ Factor } \\
\hline Management support & 2 & 6 & 20 & 37 & 66 & 18 & 4.44 & 1.067 & -0.967 & -0.641 & 0.934 \\
\hline \multicolumn{12}{|l|}{ Items } \\
\hline I trust my direct line manager & 8 & 4 & 12 & 17 & 69 & 42 & 4.72 & 1.309 & -1.399 & 1.556 & 0.926 \\
\hline I can communicate easily with my line manager & 3 & 4 & 7 & 17 & 73 & 48 & 4.95 & 1.082 & -1.594 & 3.037 & 0.929 \\
\hline My line manager has my best interests at heart & 7 & 9 & 14 & 35 & 54 & 34 & 4.45 & 1.337 & -0.922 & 0.323 & 0.922 \\
\hline Other people in our team work well with this line manager & 2 & 5 & 13 & 38 & 72 & 23 & 4.58 & 1.036 & -0.994 & 1.286 & 0.931 \\
\hline My line manager supports my individual career development & 6 & 7 & 11 & 36 & 54 & 39 & 4.58 & 1.286 & -1.04 & 0.775 & 0.921 \\
\hline My line manager conducts regular performance appraisals & 16 & 17 & 19 & 37 & 49 & 15 & 3.86 & 1.489 & -0.55 & -0.722 & 0.933 \\
\hline My line manager conducts fair performance appraisals & 16 & 11 & 21 & 29 & 56 & 18 & 4.01 & 1.499 & -0.698 & -0.523 & 0.931 \\
\hline My supervisor communicates clearly & 8 & 9 & 17 & 24 & 63 & 32 & 4.44 & 1.371 & -0.984 & 0.262 & 0.92 \\
\hline My supervisor gives constructive feedback & 10 & 14 & 20 & 32 & 48 & 29 & 4.18 & 1.462 & -0.643 & -0.482 & 0.919 \\
\hline
\end{tabular}

M, mean; SD, standard deviation; Skew, skewness; Kurt, kurtosis; $\alpha$, alpha.

The results in Table 3 show reliabilities of 0.934 for the management support scale and its items, which is well above the 'very high' rating that Hinkin $(1995$, p. 979) gives to reliabilities above 0.8 . The sample is negatively skewly distributed. The results show that, on average, the respondents were in agreement that the management support they receive was adequate. This finding applied to most of the items, except when performance appraisals were considered. The respondents only slightly agreed that their line managers conduct regular and fair performance appraisals, or give constructive feedback.

\section{Factors that will encourage academics to leave their HEls}

For the purposes of this research, the respondents were asked, firstly, to indicate whether they had been seeking alternative employment by choosing one or more responses out of the eight options provided. Secondly, they were asked to choose their top five reasons, out of 18 options provided, why they would consider leaving their HEIs. The results of the job search-related items are reported in Table 4.

The results in Table 4 show that the most frequently selected job search choice was that of $31.4 \%$ respondents who had applied for a job at another academic institution, followed by $28.1 \%$ who had applied for a promotion in the same institution and $24.2 \%$ who had looked for a job in sectors other than academia. Only $25.5 \%$ of respondents had not sought any another position. Respondents could choose more than one response, thus the percentages reflect the number of respondents who selected a particular option. Next, the respondents were asked to indicate the top five reasons why they would leave the institution. The results are reported in Table 5.

The results in Table 5 show that academics in the sample are most likely to leave the institution for the following reasons: dissatisfaction with financial compensation (54.2\%), offer of a promotion $(46.4 \%)$, unhappy about career development opportunities (41.2\%), retirement $(41.2 \%)$ and offer of higher pay in another company $(38.6 \%)$. Only retirement is not a voluntary or avoidable form of turnover. Respondents could

\begin{tabular}{lcc} 
TABLE 4: Results for job search-related items. & $\boldsymbol{f}$ & $\mathbf{\%}$ \\
\hline Item & 26 & 17.0 \\
\hline Yes, in the same institution in a different section & 43 & 28.1 \\
Yes, applied for a promotion in the same institution & 48 & 31.4 \\
Yes, at another academic institution & 37 & 24.2 \\
Yes, in another organisation (not in academia) & 10 & 6.5 \\
Yes, but I only placed my CV on the web & 37 & 24.2 \\
No, but I have been headhunted by another organisation & 17 & 11.1 \\
No, but I have been approached by a recruiting agency & 39 & 25.5 \\
\hline No & &
\end{tabular}

f, frequency; CV, curriculum vitae.

TABLE 5: Potential reasons for leaving the institution.

\begin{tabular}{lccc}
\hline Reason & $f$ & $\%$ & Rank \\
\hline Unhappy about financial compensation & 83 & 54.2 & 1 \\
\hline Unhappy about company policies & 40 & 26.1 & 6 \\
\hline Unhappy about career development opportunities & 63 & 41.2 & 3 \\
\hline Unhappy about training opportunities & 15 & 9.8 & 16 \\
\hline Unhappy about the job itself & 25 & 16.3 & 13 \\
\hline Unhappy about the number of hours I am required to work & 24 & 15.7 & 14 \\
\hline Unhappy about the people I have to work with & 19 & 12.4 & 15 \\
\hline Would leave for a promotion & 71 & 46.4 & 2 \\
\hline Would leave for more pay in another company & 59 & 38.6 & 4 \\
\hline Would leave for a job closer to home & 25 & 16.3 & 13 \\
\hline Would leave for a career change & 30 & 19.6 & 10 \\
\hline Would leave to start my own business & 27 & 17.6 & 12 \\
\hline Retirement & 63 & 41.2 & 3 \\
\hline Would only leave if I was retrenched & 28 & 18.3 & 11 \\
\hline Would leave for ill health or disability & 37 & 24.2 & 7 \\
\hline Would leave for personal reasons such as family responsibilities & 46 & 30.1 & 5 \\
\hline Would leave if my spouse was transferred & 30 & 19.6 & 9 \\
\hline Would leave to study further & 33 & 21.6 & 8 \\
\hline
\end{tabular}

$f$, frequency.

choose more than one response, thus the percentages reflect the number of respondents who selected a particular option.

\section{Satisfaction with institutional practices}

The 17-item satisfaction with institutional practices scale obtained an acceptable KMO measure of 0.882 for factor analysis. Exploratory factor analysis using the principal component method was conducted on the 17-item measure. The results showed three underlying factors that explained $64.627 \%$ of the variance. The factors were labelled as follows: satisfaction with general institutional practices (factor 1), 
satisfaction with institutional funding opportunities (factor 2) and satisfaction with diversity and community service (factor 3). All items showed acceptable loadings, ranging from 0.516 to 0.879 . The pattern matrix was obtained using an Oblimin rotation method with Kaiser normalisation and is reported in Table 6.

The descriptive statistics and reliabilities of the three factors and the items are reported in Table 7.

The results showed acceptable reliabilities for the diversity and community service items (0.783), high reliabilities for satisfaction with institutional funding (0.836) and very high reliabilities for the satisfaction with general institutional practices (0.923) following the descriptions of Field (2009). The sample was negatively skewly distributed. The results need to be interpreted considering the four-point Likert scale used in this scale, which was chosen to encourage a stronger opinion from the respondents between satisfaction and dissatisfaction. The results for the scales further showed that the respondents are mostly satisfied with institutional practices (68\%), funding opportunities (69.4\%) and diversity and community service practices (56.5\%). At the item level, the respondents were somewhat dissatisfied with the talent management practices of the institution (51\%) and mentorship opportunities for academic staff (53\%). The

TABLE 6: Pattern matrix for satisfaction with institutional practices scale.

\begin{tabular}{|c|c|c|c|}
\hline Item & $\begin{array}{c}\text { General institutional } \\
\text { practices }\end{array}$ & $\begin{array}{c}\text { Institutional funding } \\
\text { opportunities }\end{array}$ & $\begin{array}{l}\text { Diversity and community } \\
\text { service }\end{array}$ \\
\hline Sufficient access to information to do job & 0.656 & 0.106 & -0.103 \\
\hline Support from the HR department & 0.817 & -0.002 & -0.084 \\
\hline Changes and restructuring in the institution & 0.744 & -0.071 & 0.164 \\
\hline Opportunity to engage in community service projects & -0.028 & 0.356 & 0.516 \\
\hline Affirmative action & 0.037 & 0.045 & 0.769 \\
\hline Sufficient cultural diversity in the institution & -0.005 & 0.030 & 0.791 \\
\hline Sufficient respect for my culture in the institution & 0.228 & -0.111 & 0.736 \\
\hline Institutional leadership & 0.879 & -0.175 & 0.160 \\
\hline Institutional values & 0.726 & 0.048 & 0.181 \\
\hline Institutional strategy & 0.835 & -0.098 & 0.101 \\
\hline Communication from leadership & 0.858 & 0.034 & 0.016 \\
\hline Talent management policies in the institution & 0.788 & 0.085 & -0.070 \\
\hline Mentorship opportunities for academic staff & 0.622 & 0.233 & -0.059 \\
\hline Funding for research publications from the institution & 0.073 & 0.861 & -0.045 \\
\hline Research funding from external bodies such as the National Research Foundation & -0.001 & 0.778 & 0.134 \\
\hline Funding from the Institution for professional registrations & -0.010 & 0.723 & 0.143 \\
\hline
\end{tabular}

$H R$, human resource.

TABLE 7: Descriptive statistics and reliabilities of satisfaction with retention scale.

\begin{tabular}{|c|c|c|c|c|c|c|c|c|c|}
\hline Factors and items & $\begin{array}{l}\text { Extremely } \\
\text { dissatisfied }\end{array}$ & Dissatisfied & Satisfied & $\begin{array}{l}\text { Extremely } \\
\text { satisfied }\end{array}$ & M & SD & Skew. & Kurt. & $\alpha$ \\
\hline \multicolumn{10}{|l|}{ Factors } \\
\hline General institutional practices & 5 & 39 & 82 & 12 & 2.7222 & 0.61 & -0.327 & 0.183 & 0.923 \\
\hline Funding & 11 & 30 & 78 & 15 & 2.6715 & 0.666 & -0.442 & 0.202 & 0.836 \\
\hline Diversity and community service & 7 & 66 & 84 & 11 & 2.7348 & 0.608 & -0.467 & 0.977 & 0.783 \\
\hline \multicolumn{10}{|l|}{ Items } \\
\hline Sufficient access to information to do job & 2 & 20 & 91 & 39 & 3.1 & 0.659 & -0.388 & 0.368 & 0.922 \\
\hline Support from the HR department & 17 & 41 & 71 & 23 & 2.66 & 0.87 & -0.313 & -0.51 & 0.913 \\
\hline Changes and restructuring in the institution & 19 & 45 & 74 & 11 & 2.52 & 0.81 & -0.364 & -0.435 & 0.916 \\
\hline Opportunity to engage in community service projects & 10 & 29 & 93 & 21 & 2.82 & 0.747 & -0.646 & 0.521 & 0.779 \\
\hline Affirmative action & 18 & 41 & 79 & 13 & 2.58 & 0.812 & -0.439 & -0.321 & 0.705 \\
\hline Sufficient cultural diversity in the institution & 14 & 32 & 82 & 22 & 2.75 & 0.821 & -0.532 & -0.061 & 0.707 \\
\hline Sufficient respect for my culture in the institution & 11 & 24 & 97 & 21 & 2.84 & 0.747 & -0.778 & 0.787 & 0.72 \\
\hline Institutional leadership & 12 & 38 & 83 & 20 & 2.73 & 0.788 & -0.449 & -0.046 & 0.922 \\
\hline Institutional values & 11 & 28 & 85 & 26 & 2.84 & 0.795 & -0.598 & 0.213 & 0.913 \\
\hline Institutional strategy & 10 & 41 & 80 & 20 & 2.73 & 0.774 & -0.361 & -0.093 & 0.916 \\
\hline Communication from leadership & 13 & 46 & 71 & 22 & 2.67 & 0.828 & -0.241 & -0.421 & 0.906 \\
\hline Talent management policies in the institution & 16 & 60 & 64 & 10 & 2.45 & 0.774 & -0.107 & -0.392 & 0.912 \\
\hline Mentorship opportunities for academic staff & 21 & 49 & 68 & 14 & 2.49 & 0.846 & -0.212 & -0.582 & 0.909 \\
\hline Funding to attend conferences from the institution & 21 & 34 & 78 & 20 & 2.63 & 0.879 & -0.446 & -0.469 & 0.907 \\
\hline Funding for research publications from the institution & 15 & 33 & 88 & 17 & 2.7 & 0.795 & -0.597 & 0.057 & 0.913 \\
\hline $\begin{array}{l}\text { Research funding from external bodies such as the National } \\
\text { Research Foundation }\end{array}$ & 14 & 31 & 85 & 20 & 2.74 & 0.806 & -0.582 & 0.054 & 0.923 \\
\hline Funding from the Institution for Professional Registrations & 14 & 40 & 71 & 14 & 2.61 & 0.803 & -0.37 & -0.272 & 0.812 \\
\hline
\end{tabular}

M, mean; SD, standard deviation; Skew, skewness; Kurt, kurtosis; $\alpha$, alpha. 
item with the highest mean (3.10) indicated respondent satisfaction with sufficient access to information in order to do their jobs in $85.5 \%$ of the sample. Diversity items include sufficient respect for culture $(77 \%$ of respondents indicated satisfaction), sufficient cultural diversity in the institution (67.9\% of respondents indicated satisfaction) and satisfaction with affirmative action ( $60 \%$ of respondents).

\section{Intention to quit}

The three-item intention to quit scale obtained an acceptable KMO MSA of 0.752 for factor analysis. Due to the variation in wording from Cohen's (1993) intention to quit scale, exploratory factor analysis was conducted using the principal component method and this showed one underlying factor that explained $85.649 \%$ of the variance. The items showed acceptable loadings ranging from 0.909 to 0.938 . The factor was labelled intention to quit. The descriptive statistics and reliability of the intention to quit scale are reported in Table 8 .

The results in Table 8 show a Cronbach's alpha of 0.914 for reliability for the intention to quit scale with revised wording which is very high using the Field (2009) rating. Looking at the mean score of 2.9 (using the six-point scale) and the frequency distribution of the scale, it is evident that more than half of the respondents intend to stay in their current institution. The frequency analysis reveals that $66.2 \%$ of the respondents indicate a slight to strong intention to remain at their institutions whilst $33.8 \%$ indicate a slight to strong intention to quit their institutions. Of the academics who intend to quit their institutions $20 \%$ strongly agree that they intend to quit.

\section{Discussion}

The main objective of the research was to investigate and validate the factors that influence the retention of academic staff in South African public HEIs. More specifically, the research sought to determine the factors that would encourage the academics to stay, factors that would encourage academics to leave, academics' satisfaction with institutional practices and academics' intention to quit. A discussion of the most significant results is now provided.

\section{Compensation and recognition}

The exploratory factor analysis for the compensation and recognition scale items resulted in one factor, which was labelled compensation and recognition. The factor explained adequate variance for the measurement. The items showed acceptable loading and no items were deleted. The reliability analysis showed very high reliabilities for the overall compensation and recognition scale and its items. It can therefore be concluded that the compensation and recognition scale is a valid and reliable measure and may be included in the talent retention diagnostic tool.

Compensation practices as identified by the scale were found to be less than satisfactory for $52.7 \%$ of the sample. The most problematic compensation practice for the current sample was that the bonus structure does not adequately reflect the employee's contribution to the organisation. These results are not surprising, and again echo previous reports that there is a lack of properly applied bonus structures designed for the academic context (see CHE, 2008; HESA, 2011; Ngobeni $\&$ Bezuidenhout, 2011). Compensation items were crossreferenced at other points in the talent retention diagnostic tool. Thus, being unhappy about financial compensation was identified as the most likely reason that employees in the sample would consider leaving their institution (see Table 5) and leaving for more pay in another company as the fourth most likely reason. Compensation emerges as a potential turnover factor and less so as a potential retention factor for the current sample.

Although the majority of employees in the present study perceived adequate emotional recognition (57\% of sample), this still implies that $43 \%$ of the employees do not perceive the emotional recognition they receive to be adequate. Ngobeni and Bezuidenhout (2011), for example, report that inadequate employee recognition was linked to lower employee engagement and higher turnover intentions in a South African HEI. Emotional recognition as described in the talent retention scale in the present study seems to align theoretically with works psychodynamic theory where employees need a symbolic reward in the form of 'appreciation', a sense of 'acknowledgement' or 'gratitude' for their dedication or contributions (Brun \& Dugas, 2008, p. 721). Inadequate recognition can potentially be addressed by leadership development programmes which educate supervisors on a variety of suitable recognition practices to address various forms of employee recognition (Brun \& Dugas, 2008; Hinkin \& Schriesheim, 2009). Historically, appointments in HEIs have not been made based on leadership and people management skills but rather based on academic skills such as teaching and research (HESA, 2009). Emotional recognition is a potential employee retention factor in the present study.

\section{Support from manager, supervisor or direct line manager}

The exploratory factor analysis for the management support scale resulted in one factor, which was labelled management support. The factor explained adequate variance for the measurement. The items showed acceptable loading, and no item was deleted. The reliability analysis showed very high reliabilities for the overall management support scale

TABLE 8: Descriptive statistics and reliabilities of intention to quit scale.

\begin{tabular}{lccccccccccc}
\hline Factor & Strongly disagree & Disagree & Slightly disagree & Slightly agree & Agree & Strongly agree & $\mathbf{M}$ & SD & Skew. & Kurt. & $\boldsymbol{\alpha}$ \\
\hline Intention to quit & 37 & 29 & 36 & 21 & 14 & 17 & 2.9803 & 1.6007 & 0.432 & -0.939 & 0.914 \\
\hline
\end{tabular}

M, mean; SD, standard deviation; Skew, skewness; Kurt, kurtosis; $\alpha$, alpha. 
and its items. It can therefore be concluded that the scale is a valid and reliable measure, and may be included in the talent retention diagnostic tool.

Regarding management support, the results, on average, show that the respondents agreed that the direct line management support they receive is adequate. From this finding, it can be deduced that direct line managers in HEIs are adequate in managing their employees which is in line with Salopek (in Netswera et al., 2005). The adequacy of perceived line management support has been identified as a potential retention factor for the respondents in the present sample. Although correlations were not conducted in the present study, there are indications from the literature that the perceived supervisor support relationship contributes distinctly and independently to employee outcomes such as turnover intentions (Kuvaas \& Dysvik, 2010). In addition there are indications that the commitment of employees to supervisors is related to both turnover intentions and actual turnover (Vandenberghe \& Bentein, 2009). Thus, the decision to measure the adequacy of direct line management or supervisory support should be included in future measures of retention of academics.

The finding of adequacy of direct line management support applied to most of the items, except when performance appraisals were considered. The respondents only slightly agreed that their line managers conduct regular and fair performance appraisals or give constructive feedback. These findings show scope for improvement of performance appraisal and feedback practices, as previous research showed that poor and unfair application of performance management practices can result in academics leaving an institution (see Pienaar \& Bester, 2006, 2008). Ngobeni and Bezuidenhout (2011) found feedback practices to be inadequate within a single HEI and recommend that supervisors provide feedback throughout the year in order to improve employee engagement.

\section{Satisfaction with institutional practices}

The exploratory factor analysis for the satisfaction with institutional practices scale resulted in three factors, which were labelled satisfaction with general institutional practices, satisfaction with institutional funding opportunities and satisfaction with diversity and community service. The three factors explained adequate variance for the measure. The items showed acceptable loadings, and no items were deleted. The reliability analysis showed acceptable to very high reliabilities for the overall satisfaction with institutional practices scale and its items. It can therefore be concluded that the scale is a valid and reliable measure, and may be included in the talent retention diagnostic tool.

The results show that the respondents indicated being mostly satisfied with general institutional practices, funding opportunities and diversity and community service practices. General institutional practices include human resources practices in the present research. It is important to consider findings in literature that employees' perception of HR practices and policies influence employee outcomes such as commitment to their work, retention and commitment to their organisation (Purcell \& Hutchinson, 2007). In addition, performance and behaviour could be due to employees' perception of how their direct line managers implement HR practices and policies (Purcell \& Hutchinson, 2007). For example, employees may perceive (rightly or wrongly) that their direct line manager fails to initiate mentorship opportunities or training and development opportunities.

Satisfaction with opportunities to engage in community service practices is of special interest as philanthropic outreach activities are regarded as one of the key goals of HEIs together with academic research and teaching (HESA, 2009). In the present sample, $74.5 \%$ of respondents expressed satisfaction with this item. The remaining diversity items in the scale indicate sufficient respect for culture $(77 \%$ satisfaction), sufficient cultural diversity (67.9\% express satisfaction) and satisfaction with affirmative action (60\%). These results are encouraging although further improvements would be desirable as managing diversity remains a central objective for developing the next generation of academics (HESA, 2011).

At the item level, the respondents indicated the most dissatisfaction with the talent management practices of their institutions and mentorship opportunities for academic staff. The results are in line with those of previous researchers who suggest that talent management practices seem to be neither an operational nor a strategic priority in South African HEIs (see Hazelkorn \& Moynihan, 2010; Robyn, 2012).

\section{Intention to quit scale}

Exploratory factor analysis for the intention to quit scale with revised wording resulted in one factor, which was labelled intention to quit. The factor explained adequate variance for the measure. The items showed acceptable loading, and no items were deleted. The reliability analysis showed very high reliabilities (0.914) for the intention to quit scale and its items. The results are in line with previous research that also found the intention to quit scale to be a reliable measure in the South African context (Du Plessis et al., 2010; Veldtman, 2011). It can therefore be concluded that the intention to quit scale using the modified wording is a valid and reliable measure, and may be included in the overall talent retention diagnostic tool.

The results of the intention to quit scale indicate that $33.8 \%$ of the respondents were considering quitting their institutions and thus support previous research highlighting the turnover propensity of academics in South African HEIs (see CHE, 2008; HESA, 2011; Pienaar \& Bester, 2008; Robyn, 2012). Although this finding only indicates an intention to quit, it is important to note that intentions can eventually lead to actual turnover (Zhao et al., 2007). 


\section{Factors that could encourage employees to leave}

The most frequently selected job search choice was application for a job at another academic institution (31.4\%), followed by application for a promotion in the same institution $(28.1 \%)$ and search for a job in sectors other than academia (24.2\%). The results clearly show that the respondents are looking for opportunities to advance their careers, within and outside of academia. Only $25.5 \%$ of respondents had not sought any another position, meaning that $74.5 \%$ of respondents had looked for other job opportunities.

The top five reasons indicated by the respondents as to why they would consider leaving their institutions are dissatisfaction with financial compensation (54.2\%), offer of a promotion $(46.4 \%)$, unhappiness about career development opportunities (41.2\%), retirement (41.2\%) and offer of higher pay in another company (38.6\%). Only retirement is not a voluntary or avoidable form of turnover and respondents report a mix of push and pull factors. Labour market and external factors have been described as 'pull factors' (Lee \& Mitchell, 1994, p. 51) and in the present research would include leaving for a promotion and higher pay in another company. The results again show that compensation of academics remains a recurrent theme and a factor that may cause them to leave an institution. Another significant finding is the lack of promotional opportunities, which is in line with the findings of Bitzer (2008), who indicated that the inconsistent application of promotion policies in higher education institutions can lead to the deterioration of the professoriate. The present study also found a lack of career development opportunities for academics, which confirms the findings of the report by HESA (2011) highlighting the inadequate developmental opportunities available to academic staff.

\section{Limitations and recommendations}

The research has some limitations. The results of the overall study can only be generalised to academics, and not to employees in other organisations. Furthermore, this research made use of self-report measures which have the potential to result in measurement error and common method bias due to influences such as social desirability, acquiescent biases or transient mood states (Podsakoff, MacKenzie, Lee \& Podsakoff, 2003; Spector, 1994). The sample size was deemed inadequate for correlations between turnover intentions and the various retention factors. As mentioned previously, this research forms part of a scale development process which will include a validation study with a larger sample suitable for additional statistical analysis. Convergent validity was not tested in the present sample and directions for further research could include administration of scales that measure similar constructs such as employee engagement and perceived supervisor support. The talent retention diagnostic scale could be administered to employees in a variety of different organisations to determine if the validity and reliability findings will apply in different contexts. Further research using qualitative methods on the psychological dimension of turnover and retention of academics is recommended.
The recommendations from this study are that the national government revisit and increase the budget allocation for academic salaries. In addition, HEIs should also focus on designing suitable incentives and perks for academic staff, and offer fair and equitable bonus structures. Emotional recognition is a potential retention factor that can be addressed with an adequate leadership development programme that educates direct line managers in suitable recognition practices. HEIs should endeavour to create suitable job descriptions for academic staff members, with clear and measureable performance outputs in order to improve the performance management system as a retention factor. Career-path development and mentorship for academics should be more robust and reinforced for academic institutions. Finally, although HEIs emphasise the importance of employment equity practices, these should be applied in a manner that would benefit all racial groups and not allow for discriminatory practices.

\section{Conclusion}

This study shows that $34 \%$ of academics in this sample are considering quitting their current institution and unhappiness with compensation emerges as the most likely reason for academics to leave their current job. This research makes important contributions on a theoretical, methodological and practical level. The major theoretical contribution of this study is the addition of sound empirical evidence for the turnover and retention factors that could encourage academics to leave or stay in higher education institutions in South Africa, as well as their current level of satisfaction with institutional practices and direct line management support. From a methodological point of view, the research provides evidence that the new talent retention diagnostic tool is a valid and reliable measure to determine the factors that contribute to the retention of academics in South African HEIs. From a practical point of view, the research highlights the following turnover risks and potential retention factors that higher education should attend to if they want to retain their key and talented academic staff: compensation, emotional recognition, a bonus structure that reflects employee contribution, improved implementation of performance management systems, regular feedback, promotional opportunities, talent management policies, career development opportunities and mentorship opportunities.

\section{Acknowledgements Competing interests}

The authors declare that they have no financial or personal relationship(s) that may have inappropriately influenced them in writing this article.

\section{Authors' contributions}

The research is based on the doctoral study of M.T. (University of Pretoria) that is currently in progress. This article presents a part of the research. N.B. (University of Pretoria and NorthWest University) is the promoter of the research and Y.d.P. 
(University of Pretoria) the co-promoter. All three authors made an equal contribution to the article.

\section{References}

Allen, D.G., \& Griffeth, R.W. (1999). Job performance and turnover: A review and integrative multi-route model. Human Resource Management Review, 9(4), 525-548. $\mathrm{http}: / / d x . d o i . o r g / 10.1016 /$ S1053-4822(99)00032-7

Allen, D.G., Shore, L.M., \& Griffeth, R.W. (2003). The role of perceived organizational support and supportive human resource practices in the turnover process. Journal of Management, 29(1), 99-118. http://dx.doi.org/10.1177/014920630302900107

Bitzer, E.M. (2008). The professoriate in South Africa: Potentially risking status inflation. South African Journal of Higher Education, 22, 265-281.

Bontis, N. \& Fitz-enz, J. (2002). Intellectual capital ROI: A causal map of human capital antecedents and consequents. Journal of Intellectual Capital, 3(3), 223-247. http:// dx.doi.org/10.1108/14691930210435589

Boshoff, C., \& Mels, G. (2000). The impact of multiple commitments on intentions to resign: An empirical assessment. British Journal of Management, 11(3), 255-272. http://dx.doi.org/10.1111/1467-8551.00165

Botha, L.S. \& Potgieter, F.J. (2009). Understanding skills development in South African higher education institutions. SA Journal of Higher Educations, 23(2), 246-263.

Brun, J.-P. \& Dugas, N. (2008). An analysis of employee recognition: Perspectives on human resources practices. The International Journal of Human Resource Management, 19(4), 716-730. http://dx.doi.org/10.1080/09585190801953723

Buddeberg-Fischer, B., Stamm M., \& Buddeberg, C. (2009). Academic career in medicine - Requirements and conditions for successful advancement in Switzerland. BMC Health Serv Res, 9(70), 1-14.

Cascio, W.F. (2006). The economic impact of employee behaviors on organizational performance. California Management Review, 48(4), 41-59. http://dx.doi. org $/ 10.2307 / 41166360$

Cohen, A. (1993). Work commitment in relation to withdrawal intentions and union effectiveness. Journal of Business Research, 26, 75-90. http://dx.doi.org/10.1016/ 0148-2963(93)90044-P

Council on Higher Education (CHE). (2008). The state of higher education in South Africa. Higher Education Monitor No. 8. Pretoria: Council on Higher Education.

De Villiers, A.P., \& Steyn, A.G.W. (2009). Effect of changes in state funding of higher education output in South Africa: 1986-2007. South African Journal of Higher Education, 22, 43-68.

DeVellis, R.F. (1991). Scale development: Theory and applications. Applied Social Research Methods Series: 26. Newbury Park, CA: Sage.

Du Plessis, L., Stanz, K., \& Barkhuizen, E.N. (2010). The relationship between perceived talent management practices, perceived organizational support (POS), perceived supervisor support (PSS) and intention to quit amongst Generation Y employees in supervisor support (PSS) and intention to quit amongst Generation Y employees in the recruitment sector. Paper presented at the 3rd Annual People and

Field, A. (2009). Discovering statistics using SPSS. (2nd edn.). London: Sage Publications.

Garson, D.G. (2011). Factor analysis. North Carolina State University Quantitative Research in Public Administration. Retrieved May 28, 2011, from http://faculty. chass.ncsu.edu/garson/PA765/factor.htm

Hair, J.F., Black, W.C., Babin, B.J., \& Anderson, R.E. (2010). Multivariate data analysis: A global perspective. (7th edn.). New Jersey: Pearson Education. http://dx.doi. org/10.1016/j.jmva.2009.12.014

Harman, W.S., Lee, T.W., Mitchell, T.R., Felps, W., \& Owens, B.P. (2007). The psychology of voluntary employee turnover. Current Directions in Psychological Science, 16(1) 51-54. http://dx.doi.org/10.1111/j.1467-8721.2007.00474.x

Hay, M. (2002). Strategies for survival in the war of talent. Career Development International, 7(1), 52-55. http://dx.doi.org/10.1108/13620430210414883

Hazelkorn, E., \& Moynihan, A. (2010). Transforming academic practice: Human resources challenges. In S. Kyvik, \& B. Lepori, (Eds.), The Research Mission of Higher Education Institutes outside the University Sector (pp. 77-96). Dordrecht: Springer. http://dx.doi.org/10.1007/978-1-4020-9244-2_5

Higher Education South Africa (HESA). (2009). First among equals: Stories from higher education leaders in South Africa. Pretoria: University of South Africa.

HESA. (2011). A generation of growth: Proposal for a national programme to develop the next generation of academics for South African higher education. Pretoria: University of South Africa.

Hinkin, T.R. (1995). A review of scale development practices in the study of organizations. Journal of Management, 21(5), 967-988.

Hinkin, T.R. \& Schriesheim, C.A. (2009). Performance incentives for tough times. Harvard Business Review, 87(3), 26-26.

Huselid, M.A. (1995). The impact of human resource management practices on turnover, productivity, and corporate financial performance. Academy of Management Journal, 38(3), 635-672. http://dx.doi.org/10.2307/256741

Jongbloed, B. (2012). Introducing market forces in academic remuneration: The case of the Netherlands. In P.G. Altbach, L. Reisberg, M. Yudkevich, G. Androushchak, \& I.F. Pacheco (Eds.). Paying the professoriate: A global comparison of compensation and contracts (pp. 234-244). New York: Routledge.

Kontoghiorghes, C. \& Frangou, K. (2009). The association between talent retention, antecedent factors and consequent organizational performance. SAM Advanced Management Journal, 74(1), 29-58.
Kuvaas, B., \& Dysvik, A. (2010). Exploring alternative relationships between perceived investment in employee development, perceived supervisor support and employee outcomes. Human Resource Management Journal, 20(2), 138-156. http://dx.doi. outcomes. Human Resource Manageme
org/10.1111/j.1748-8583.2009.00120.x

Lee, T.H., Gerhart, B., Weller, I., \& Trevor, C.O. (2008). Understanding voluntary turnover: Path-specific job satisfaction effects and the importance of unsolicited job offers. Academy of Management Journal, 51(4), 651-671. http://dx.doi. org/10.5465/AMJ.2008.33665124

Lee, T.W., \& Mitchell, T.R. (1994). An alternative approach: The unfolding model of voluntary employee turnover. Academy of Management Review, 19(1), 51-89. $\mathrm{http}: / / \mathrm{dx}$.doi.org/10.5465/AMR.1994.9410122008

Lee, T.W., Mitchell, T.R., Wise, L., \& Fireman, S. (1996). An unfolding model of voluntary employee turnover. Academy of Management Journal, 39(1), 5-36. http://dx.doi. org/10.2307/256629

Malik, M.E., \& Ghafoor, M.M. (2011). Organisational effectiveness: A case study of telecommunication and banking sector of Pakistan. Far East Journal of Psychology and Business, 2(1), 37-48.

Metcalf, H., Rolfe, H., Stevens, P., \& Weale, M. (2005). Recruitment and retention of academic staff in higher education. UK: National Institute of Economic and Social Research.

Mokoditoa, J.M. (2011). Academic staff recruitment and retention strategies at the University of Limpopo. Unpublished master's dissertation, University of Limpopo, South Africa.

Morrell, K., \& Arnold, J. (2007). Look after they leap: Illustrating the value of retrospective reports in employee turnover. International Journal of Human Resource Management 18(9), 1683-1699. http://dx.doi.org/10.1080/09585190701570759

Morrell, K., Loan-Clarke, J., \& Wilkinson, A. (2001). Unweaving leaving: The use of models in the management of employee turnover. International Journal of Management Reviews, 3(3), 219-244. http://dx.doi.org/10.1111/1468-2370.00065

Mouton, J. (2010). African experience with collaborative graduate programmes. Research report. Stellenbosch: University of Stellenbosch.

Netswera, F.G., Rankhumise, E.M., \& Mavundla, T.R. (2005). Employee retention factors for South African higher education institutions: A case study. SA Journal of Human Resource Management, 3(2), 36-40. http://dx.doi.org/10.4102/sajhrm.v3i2.64

Ng'ethe, J.M., Iravo, M.E., \& Namusonge, G.S. (2012). Determinants of staff retention in public universities in Kenya: Empirical review. International Journal of Humanities and Social Science, 2(13), 105-212.

Ngobeni, E.K., \& Bezuidenhout, A. (2011). Engaging employees for improved retention at a higher education institution in South Africa. African Journal of Business at a higher education institution

Ntshoe, P., Higgs, L.G., Higgs, C.C., \& Wolhuter, I. (2008). The changing academic profession in higher education and new managerialism and corporatism in South Africa. South African Journal of Higher Education, 22(2), 391-403. http://dx.doi. org/10.4314/sajhe.v22i2.25793

O'Reilly, C. (1991). Organisational behaviour: Where we've been, where we're going. Annual Review of Psychology, 42(1), 427-458. http://dx.doi.org/10.1146/annurev. ps.42.020191.002235

Pienaar, C., \& Bester, C.L. (2006). Die loopbaandilemmas van akademiese personeel verbonde aan ' $n$ veranderende Suid-Afrikaanse hoëronderwysinstelling. ACTA ACADEMICA, 38(3), 74-95.

Pienaar, C., \& Bester, C.L. (2008). The retention of academics in the early career phase: Empirical research. SA Journal of Human Resource Management, 6(2), 32-41.

Pinkowitz, W., Moskal, J., \& Green, G. (2009). How much does your employee turnover cost? Center for Community and Economic Development, University of Wisconsin. Retrieved June 13, 2009, from http://www.uwex.edu/ces/cced/economies/turn.cfm

Podsakoff, P.M., MacKenzie, S.B., Lee, J.Y., \& Podsakoff, N.P. (2003). Common method biases in behavioral research: A critical review of the literature and recommended remedies. Journal of Applied Psychology, 88(5), 879-903. http://dx.doi.org/10.1037/ 0021-9010.88.5.879

Purcell, J., \& Hutchinson, S. (2007). Front-line managers as agents in the HRM-performance causal chain: theory, analysis and evidence. Human Resource Management Journal, 17(1), 3-20. http://dx.doi.org/10.1111/j.1748-8583.2007.00022.x

Robison, J. (2008). Turning around employee turnover: Costly churn can be reduced if managers know what to look for - and they usually don't. Gallup Management Journal Online, 08 May, 1-6.

Robyn, A.M. (2012). Intention to quit amongst Generation $Y$ academics at higher education institutions. Unpublished master's dissertation, Stellenbosch University, Stellenbosch, South Africa.

Shaw, J.D., Delery, J.E., Jenkins, G.D., \& Gupta, N. (1998). An organization-level analysis of voluntary and involuntary turnover. Academy of Management Journal, 41(5), 511-525. http://dx.doi.org/10.2307/256939

Shaw, J.D. \& Gupta, N. (2007). Pay system characteristics and quit patterns of good, average and poor performers. Personnel Psychology, 60(4), 903-928. http://dx.doi. org/10.1111/j.1744-6570.2007.00095.x

Smither, L. (2003). Managing employee life cycles to improve labor retention. Leadership \& Management in Engineering, 3(1), 19-23. http://dx.doi.org/10.1061/(ASCE)15326748(2003)3:1(19)

Somaya, D. \& Williamson, I.O. (2008). Rethinking the 'war for talent'. MIT Sloan Management Review, 49(4), 29-34.

Spector, P.E. (1994). Using self-report measures in OB research: A comment on the use of a controversial method. Journal of Organizational Behavior, 15(5), 385-392. http://dx.doi.org/10.1002/job.4030150503

SPSS Inc. (2013). SPSS 21 for Windows. Chicago, IL: Author. 
Steel, R.P. (2002). Turnover theory at the empirical interface: Problems of fit and function. Academy of Management Review, 27(3), 346-360. http://dx.doi.org/ 10.2307/4134383

Tabachnick, B.G. \& Fidell, L.S. (2001). Using multivariate statistics. (4th edn.). Boston: Allyn \& Bacon.

Tanova, C. \& Holtom, B.C. (2008). Using job embeddedness factors to explain voluntary turnover in four European countries. International Journal of Human Resource Management, 19(9), 1553-1568. http://dx.doi.org/10.1080/09585190802294820

Taylor, J.L., Murphy, B., \& Price, W. (2006). Goldratt's thinking process applied to employee retention. Business Process Management Journal, 12(5), 646-670. http://dx.doi. org/10.1108/14637150610691055

Tharenou, P., Donohue, R., \& Cooper, B. (2007). Management research methods. Cambridge: Cambridge University. http://dx.doi.org/10.1017/CBO9780511810527

Theron, M. (2012). Talent retention diagnostic tool. Unpublished.

Vandenberghe, C. \& Bentein, K. (2009). A closer look at the relationship between affective commitment to supervisors and organizations turnover. Journal of Occupational and Organizational Psychology, 82, 331-348.
Veldtman, G. (2011). The impact of talent management practices on the retention of employees. Unpublished master's thesis, University of Pretoria, Pretoria, South Africa.

Waldman, J.D. \& Arora, S. (2004). Measuring retention rather than turnover: A different and complementary HR calculus. Human Resource Planning, 27(3), 6-9.

Whitford, C., \& Coetsee, W. (2006). A model of the underlying philosophy and criteria for effective implementation of performance management. SA Journal of Human Resource Management, 4(1), 63-73. http://dx.doi.org/10.4102/sajhrm.v4i1.78

Whitt, W. (2006). The impact of increased employee retention on performance in a customer contact centre. Manufacturing \& Service Operations Management, 8(3), 235-252. http://dx.doi.org/10.1287/msom.1060.0106

Williamson, P.J. \& Zeng, M. (2009). Value-for-money strategies for recessionary times. Harvard Business Review, 87(3), 66-74.

World Economic Forum (WEF). (2011). Global Competitiveness Report 2011-2012. Geneva, Switzerland: WEF.

Zhao, H., Wayne, S.J., Glibkowski, B.C., \& Bravo, J. (2007). The impact of psychological contract breach on work-related outcomes: A meta-analysis. Personnel Psychology 60(3), 647-680. http://dx.doi.org/10.1111/j.1744-6570.2007.00087.x 